Disclosure of Interests: Lianne Kearsley-Fleet: None declared, Rebecca Davies: None declared, Jennifer Page: None declared, Eileen Baildam: None declared, Michael Beresford: None declared, Helen Foster: None declared, Taunton Southwood: None declared, Wendy Thomson: None declared, Kimme Hyrich Grant/research support from: Grants to institution: BMS, Pfizer, UCB DOI: 10.1136/annrheumdis-2019-eular.415

\section{OP0017 NINTEDANIB REDUCED DECLINE IN FORCED VITAL CAPACITY ACROSS SUBGROUPS OF PATIENTS WITH SYSTEMIC SCLEROSIS-ASSOCIATED INTERSTITIAL LUNG DISEASE: DATA FROM THE SENSCIS TRIAL}

Oliver Distler $^{1}$, Kristin Highland ${ }^{2}$, Martina Gahlemann ${ }^{3}$, Arata Azuma ${ }^{4}$ Aryeh Fischer $^{5}$, Maureen Mayes ${ }^{6}$, Ganesh Raghu ${ }^{7}$, Wiebke Sauter ${ }^{8}$, Mannaig Girard ${ }^{9}$, Margarida Alves ${ }^{10}$, Emmanuelle Clerisme-Beaty ${ }^{10}$, Susanne Stowasser ${ }^{10}$, Masataka Kuwana ${ }^{11}$, Toby M Maher ${ }^{12}$, SENSCIS trial investigators. ${ }^{1}$ Department of Rheumatology, University Hospital Zurich, Zurich, Switzerland; ${ }^{2}$ Respiratory Institute, Cleveland Clinic, Cleveland, Ohio, United States of America; ${ }^{3}$ Boehringer Ingelheim (Schweiz) GmbH, Basel, Switzerland; ${ }^{4}$ Department of Pulmonary Medicine and Oncology, Graduate School of Medicine, Nippon Medical School, Tokyo, Japan; ${ }^{5}$ University of Colorado School of Medicine, Denver, Colorado, United States of America; ${ }^{6}$ Division of Rheumatology and Clinical Immunogenetics, University of Texas McGovern Medical School, Houston, Texas, United States of America; ${ }^{7}$ University of Washington, Seattle, United States of America; ${ }^{8}$ Boehringer Ingelheim Pharma GmbH and Co. KG, Biberach an der Riss, Germany; ${ }^{9}$ Boehringer Ingelheim France S.A.S., Reims, France;

${ }^{10}$ Boehringer Ingelheim International $\mathrm{GmbH}$, Ingelheim am Rhein, Germany; ${ }^{11}$ Department of Allergy and Rheumatology, Nippon Medical School Graduate School of Medicine, Tokyo, Japan; ${ }^{12}$ National Heart and Lung Institute, Imperial College London, UK, and National Institute for Health Research Clinical Research Facility, Royal Brompton Hospital, London, United Kingdom

Background: In the SENSCIS trial, nintedanib reduced the progression of interstitial lung disease associated with systemic sclerosis (SSc-ILD) compared with placebo, as demonstrated by a significantly lower rate of decline in forced vital capacity (FVC) over 52 weeks (primary endpoint).

Objectives: To assess the effect of nintedanib on the rate of decline in FVC in the SENSCIS trial across pre-specified subgroups defined by baseline characteristics.

Methods: Patients with SSc-ILD with onset of first non-Raynaud symptom $<7$ years before screening and $\geq 10 \%$ fibrosis of the lungs on a high-resolution computed tomography scan were randomised to receive nintedanib $150 \mathrm{mg}$ bid or placebo double-blind. The annual rate of decline in FVC (ml/year) assessed over 52 weeks (primary endpoint) was analysed in the overall population using a random coefficient regression model (with random slopes and intercepts) including antitopoisomerase I antibody (ATA) status, age, height, gender and baseline FVC as covariates. Analyses in subgroups by baseline characteristics included additional terms for treatment-by-subgroup and treatment-by-subgroup-by-time interaction. Results: A total of 576 patients were treated (288 in each group). Most $(75.2 \%$ ) of patients were female, $51.9 \%$ had diffuse cutaneous SSc, and $48.4 \%$ were taking mycophenolate at baseline. Mean \pm SD age was $54.0 \pm 12.2$ years and $21.4 \%$ of patients were aged $\geq 65$ years. Nintedanib had a consistent effect on reducing the rate of FVC decline across pre-specified subgroups defined by baseline characteristics ( $p>0.05$ for all treatment-by-time-by-subgroup interactions) (figure).

Conclusion: Nintedanib is effective at reducing ILD progression in a broad range of patients with SSc-ILD.
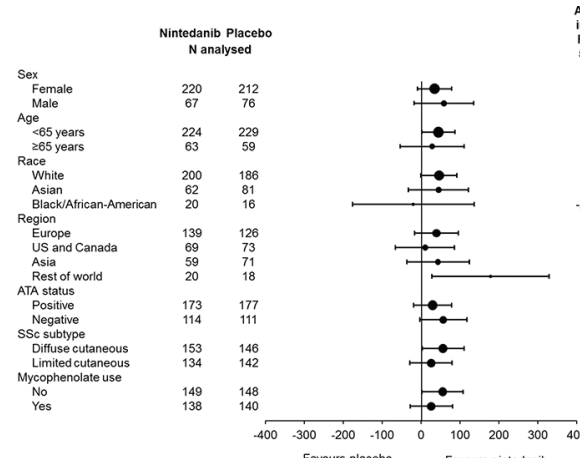

\begin{tabular}{|c|c|}
\hline $\begin{array}{l}\text { Adjusted difference } \\
\text { in rate of deceline in } \\
\text { FC (milyear) over } \\
52 \text { weeks }(95 \% \mathrm{Cr})\end{array}$ & $\begin{array}{l}\text { P-value for } \\
\text { treatment-by- } \\
\text { time-by-subgroup } \\
\text { interaction }\end{array}$ \\
\hline $\begin{array}{l}34.6(-9.3,78.4) \\
58.6(-18.0,135.1)\end{array}$ & 0.59 \\
\hline $\begin{array}{c}44.4(1.4 .87 .4) \\
28.1(-54.2,110.4)\end{array}$ & 0.73 \\
\hline $\begin{array}{c}45.8(-0.83,92.5) \\
44.5(-32.9,121.9) \\
-20.4(-176.7,136.0)\end{array}$ & 0.73 \\
\hline $\begin{array}{l}39.7(-16.6,95.9) \\
10.3(-65.6,86.1) \\
433.4-(-37.0,123.8) \\
178.4(28.1,328.7)\end{array}$ & 0.28 \\
\hline $\begin{array}{l}29.9(-19.1,78.8) \\
57.2(-3.5,118.0)\end{array}$ & 0.49 \\
\hline $\begin{array}{l}56.6(3.2,2110.0) \\
25.3(-28.9,79.6)\end{array}$ & 0.42 \\
\hline $\begin{array}{l}55.4(2.3,108.5) \\
26.3(-27.9,80.6)\end{array}$ & 0.45 \\
\hline
\end{tabular}

Figure 1

Disclosure of Interests: Oliver Distler Grant/research support from: Prof. Distler received research funding from Actelion, Bayer, Boehringer Ingelheim and Mitsubishi Tanabe to investigate potential treatments of scleroderma and its complications, Consultant for: Prof. Distler has/had consultancy relationship within the last 3 years with Actelion, AnaMar, Bayer, Boehringer Ingelheim, ChemomAb, espeRare foundation, Genentech/Roche, GSK, Inventiva, Italfarmaco, iQvia, Lilly, medac, Medlmmune, Mitsubishi Tanabe Pharma, Pharmacyclics, Novartis, Pfizer, Sanofi, Serodapharm and UCB in the area of potential treatments of scleroderma and its complications. In addition, he had/has consultancy relationship within the last 3 years with A. Menarini, Amgen, Abbvie, GSK, Mepha, MSD, Pfizer and UCB in the field of arthritides and related disorders, Kristin Highland Grant/research support from: Kristin Highland is a site PI for the SENSCIS trial (Dr Highland's institution has the contract for the study) which is funded by Boehringer Ingelheim., Consultant for: Kristin Highland is a paid consultant for Boehringer Ingelheim through her role sitting on the steering committee., Speakers bureau: Kristin Highland is on the speakers' bureau for Boehringer Ingelheim., Martina Gahlemann Employee of: Employee of Boehringer Ingelheim

Arata Azuma Consultant for: Arata Azuma has received personal fees from Boehringer Ingelheim, Shionogi \& Co., Ltd, Taiho Pharmaceutical Co., Ltd, and Asahikasei Pharma Co., Aryeh Fischer Grant/research support from: Aryeh Fischer has received a grant from Boehringer Ingelheim (Consultant/steering committee member/principal investigator on clinical trials)., Consultant for: Aryeh Fischer has received personal fees from Boehringer Ingelheim (Consultant/steering committee member/principal investigator on clinical trials), Genentech-Roche (Consultant/steering committee member/principal investigator on clinical trials), Pfizer (Consultant) and Genentech (Consultant)., Maureen Mayes Grant/research support from: Maureen Mayes is a clinical trial investigator for Boehringer-Ingelheim; Galapagos, Reata, Sanofi, Merck-Serono, Consultant for: Maureen Mayes is a member of scientific advisory boards for Galapagos NV (Pharma), Boehringer-Ingelheim, Mitsubishi-Tanabe, Astellas: Grant Review Board for Actelion. Speakers bureau: Maureen Mayes received personal fees for being a conference speaker on the use of autoantibodies in connective tissue diseases for Medtelligence, Ganesh Raghu Grant/research support from: Ganesh Raghu is the principal investigator for IPF net studies and is a steering committee member for IPF net studies for the NIH., Consultant for: Ganesh Raghu is a consultant for Boehringer Ingelheim, Bellerophan, Biogen, BMS, Fibrogen, Gilead, Nitto, Revistan, Promedior, Sanofi, Veracyte and Roche-Genentech; and a consultant and chair of the DSMB for Avalyn., Wiebke Sauter Employee of: Wiebke Sauter is an employee of Boehringer Ingelheim, Mannaig Girard Employee of: Mannaig Girard is an employee of Boehringer Ingelheim, Margarida Alves Employee of: Employee of Boehringer Ingelheim, Emmanuelle Clerisme-Beaty Employee of: Emmanuelle Clerisme-Beaty is an employee of Boehringer Ingelheim, Susanne Stowasser Employee of: Susanne Stowasser is an employee of Boehringer Ingelheim, Masataka Kuwana Grant/research support from: Actelion, Consultant for: Chugai, Reata, GlaxoSmithKline, Bayer, Boehringer-Ingelheim, Corpus, CSL-Berling, Mochida, Speakers bureau: Actelion, Pfizer, Bayer, Nippon Shinyaku, Chugai, Toby M Maher Shareholder of: Has stock options or bond holdings in a for-profit corporation in Apellis, Grant/research support from: Received funds from BI advisory board participation and conference travel. Received research funding and/o consulting fees or other remuneration from GSK, UCB, AstraZeneca, Roche, Bayer, Biogen Idec, Cipla, Prometic, and Sanumed, Consultant for: Toby Maher has received consultancy or speakers fees from Apellis, AstraZeneca, Bayer, Biogen Idec, Boehringer Ingelheim, Galapagos, GlaxoSmithKline R\&D, Indalo, Pliant, ProMetic, Roche, Samumed, and UCB; and has received consultancy fees from Galecto

DOI: 10.1136/annrheumdis-2019-eular.3323

\section{OP0018 \\ MIR-34A IS A POTENTIAL THERAPEUTIC TARGET IN OSTEOARTHRITIS}

Helal Endisha, Poulami Datta, Anirudh Sharma, Sayaka Nakamura,

Evgeny Rossomacha, Carolen Younan, Ghazaleh Tavallaee, Rajiv Gandhi, Mohit Kapoor. University Health Network, Toronto, Canada

Background: We have previously reported that microRNA-34a (miR-34a) is expressed at significantly higher levels in the synovial fluid of late-stage radiographic knee osteoarthritis (OA) compared to early-stage radiographic knee OA. Despite increased levels of miR-34a, its exact role in OA pathogenesis is largely unknown. The aim of this study was to comprehensively elucidate the role and therapeutic potential of microRNA-34 in OA.

Objectives: The aim of this study was to comprehensively elucidate the role and therapeutic potential of microRNA-34 in OA.

Methods: Human plasma, cartilage and synovium were obtained from total knee replacement (TKR) patients. Chondrocytes and synovial fibroblasts were trans fected with miR-34a mimic or inhibitor for qRT-PCR or Western blot. For in-vivo studies, mice were injected once with a in-vivo grade mir-34a mimic or control oligonucleotide and joints were collected 8 weeks post-injection for histology. Mice were subjected to destabilization of the medial meniscus (DMM) to induce OA and injected 2, 4, and 6 weeks post-surgery with miR-34a inhibitor and joints were collected 10 weeks post-surgery for histology. Heterozygous miR-34a knock out 